This item was submitted to Loughborough's Research Repository by the author.

Items in Figshare are protected by copyright, with all rights reserved, unless otherwise indicated.

\title{
Thiadiazolidine 1-oxide systems for phosphine-free palladium-mediated catalysis
}

PLEASE CITE THE PUBLISHED VERSION

http://dx.doi.org/10.1016/j.tet.2010.08.018

PUBLISHER

(C) Elsevier Ltd.

VERSION

AM (Accepted Manuscript)

LICENCE

CC BY-NC-ND 4.0

REPOSITORY RECORD

Buckley, Benjamin R., and Stephen P. Neary. 2019. "Thiadiazolidine 1-oxide Systems for Phosphine-free Palladium-mediated Catalysis”. figshare. https://hdl.handle.net/2134/13945. 
This item was submitted to Loughborough's Institutional Repository (https://dspace.lboro.ac.uk/) by the author and is made available under the following Creative Commons Licence conditions.

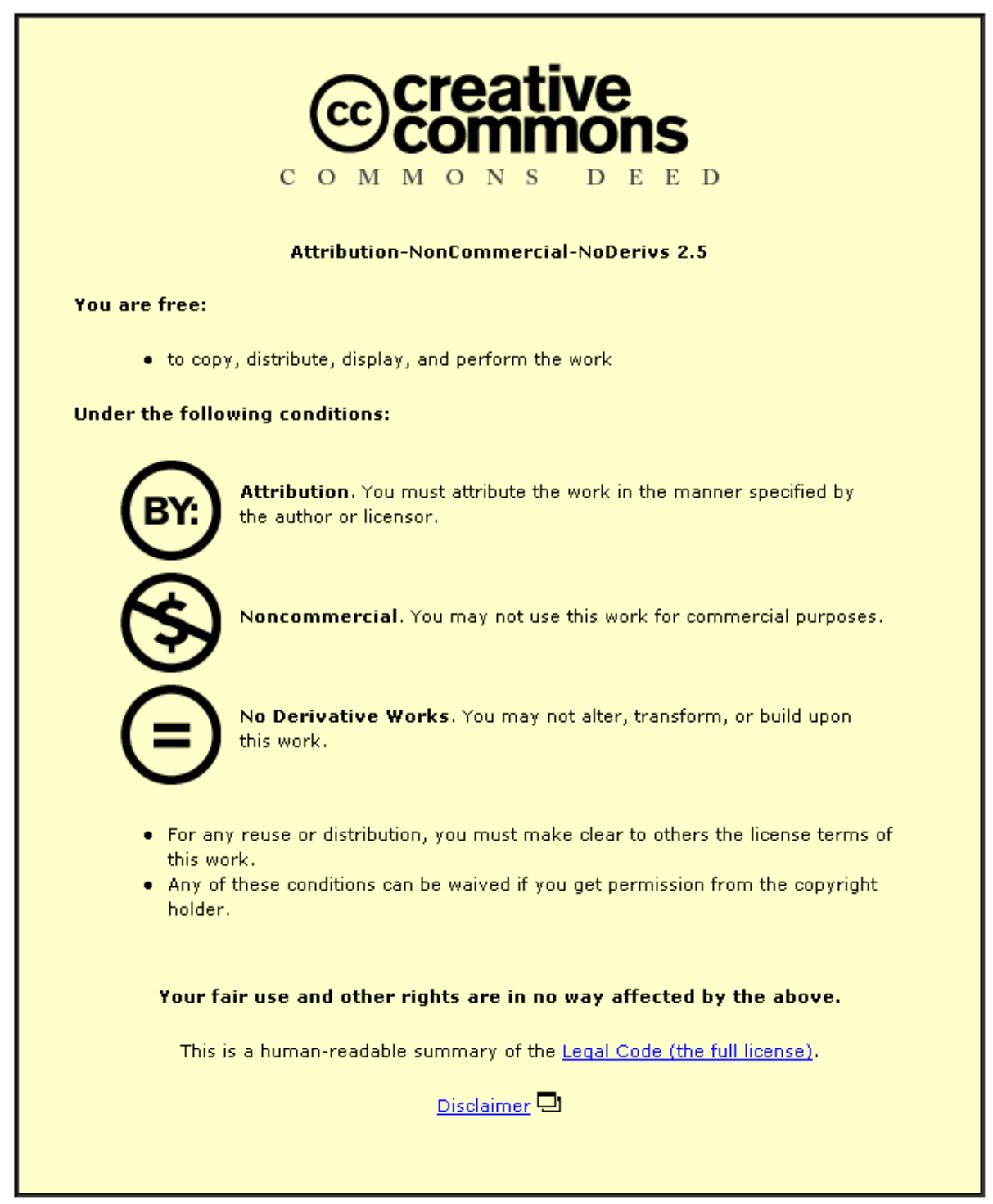

For the full text of this licence, please go to: http://creativecommons.org/licenses/by-nc-nd/2.5/ 


\section{Graphical Abstract}

To create your abstract, type over the instructions in the template box below.

Fonts or abstract dimensions should not be changed or altered.

\section{Thiadiazolidine 1-oxide Systems For Phosphine-Free Palladium-Mediated Catalysis}

Benjamin R. Buckley* and Stephen P. Neary

Department of Chemistry. Loughborough University, Ashby Road, Loughborough, Leicestershire, LE11 3TU, $U K$

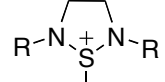

$$
\begin{aligned}
& \mathrm{R}_{{ }_{\mathrm{Br}}}+ح_{\mathrm{R}} \frac{\mathrm{Pd}(\mathrm{dba})_{2}(0.0001 \mathrm{~mol} \%),}{\mathrm{NMP}, \mathrm{NaOAc}, \mathrm{TBAB}} \rightarrow \mathrm{R}_{\mathrm{R}^{1}}
\end{aligned}
$$




\title{
Thiadiazolidine 1-oxide Systems For Phosphine-Free Palladium-Mediated Catalysis
}

\author{
Benjamin R. Buckley* and Stephen P. Neary \\ Department of Chemistry. Loughborough University, Ashby Road, Loughborough, Leicestershire, LE11 3TU, UK
}

\section{ARTICLE INFO}

\section{ABSTRACT}

\section{Article history:}

Received

Received in revised form

Accepted

Available online

\section{Keywords:}

Palladium

Catalysis

Phosphine-Free

Heck

Thiadiazolidine
We herein report several highly active catalyst systems with thiadiazolidine 1-oxides as ligands for palladium in the Mizoroki-Heck reaction. Excellent yields of stilbenes derived from aryl iodides and bromides have been achieved using as little as $0.00002 \mathrm{~mol} \%$ catalyst. The ligand/palladium system can be stored as a stock solution open to air at room temperature with no observable loss of activity for a period of several months.

2009 Elsevier Ltd. All rights reserved.

\section{Introduction}

Palladium catalysis has undeniably become an indispensable tool in organic synthesis. The Mizoroki-Heck protocol for coupling aryl halides and alkenes has achieved a special place among palladium catalysed reactions as few can match its versatility. ${ }^{1,2}$ Traditionally, phosphine ligands have been used to stabilize reactive palladium intermediates, and excellent results have been reported for Pd-catalysed Mizoroki-Heck reactions. ${ }^{3,45}$ Sterically bulky monophosphines, ${ }^{6}$ diphosphines, ${ }^{7}$ cyclometalated phosphines, and phosphites are particularly good ligands for palladium. ${ }^{8,9}$ The air-sensitivity of these types of ligands, however, can preclude their use in a variety of synthetic applications. ${ }^{10}$ Moreover, phosphine ligands are often expensive and their price can exceed that of the palladium salt. Therefore, the development of phosphine free ligands has been increasingly investigated in recent times, with $N$-heterocyclic carbenes originally reported by Arduengo, ${ }^{11}$ thioureas, independently reported by $D$. Yang ${ }^{12}$ and $Z$. Yang ${ }^{13}$ being amongst the most effective systems (Figure 1). ${ }^{14}$

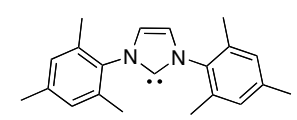

Arduengo

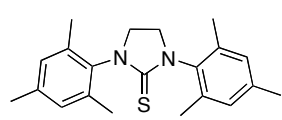

D. Yang

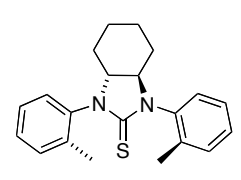

Z. Yang

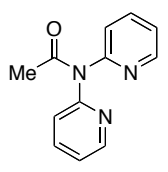

Buchmeiser
Figure 1. Phosphine free ligands for palladium
We were attracted to the thiadiazolidine oxides as we postulated that they may be interesting and useful ligands for metal-catalysed reactions. There are very few reports regarding the synthesis of thiadiazolidines $\mathbf{4}$ or thiadiazolidine oxides $\mathbf{5}$. The majority of reports regarding thiadiazolidine-1,1-dioxides $\mathbf{6}$ relate to their pharmacological properties, ${ }^{15}$ the zwitterion 7 has been used in a Mitsunobu-type reaction ${ }^{16}$ and $\mathbf{8}$ has been proposed in connection with Oppolzer's sultam model. ${ }^{17}$ Thiadiazolidine 1,1-dioxides have also been reported as useful polar aprotic solvents ${ }^{18}$ and as key intermediates for the synthesis of constrained peptides. ${ }^{19}$

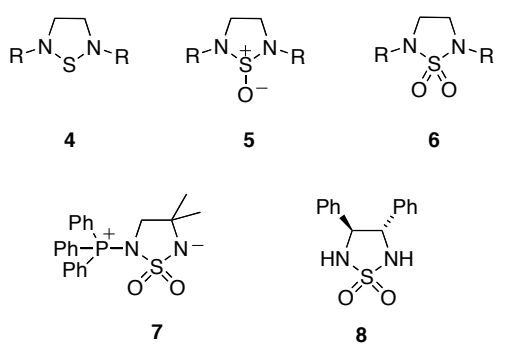

Figure 2. Thiadiazolidines

\section{Results and Discussion}

\subsection{Initial results}

We conjectured that thiadiazolidine 1-oxides might be effective ligands for palladium-mediated processes, and in order to test our hypothesis we chose to prepare the mesityl-derived thiadiazolidine oxide 9. ${ }^{20}$ This was easily achieved in two steps; mesityl amine and glyoxal were reacted neat, and upon formation of the bright yellow bis-imine, sodium borohydride/ethanol was added to furnish the bis-amine $\mathbf{1 0}$ in excellent yield (Scheme 1). 
Treatment of a solution of $\mathbf{1 0}$ in diethylether/triethylamine with thionyl chloride afforded the thiadiazolidine oxide $\mathbf{9}$ in good yield.

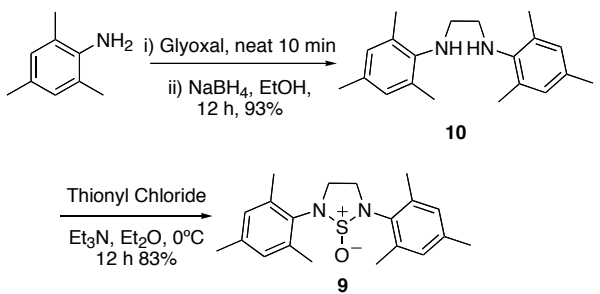

Scheme 1. Synthesis of the mesityl-derived thiadiazolidine oxide 9

With ligand 9 in hand we chose to screen a range of palladium sources, using 4-methoxy-iodobenzene and styrene, as our test system, and carried out the reactions under microwave irradiation. ${ }^{21}$ We found that the system reported by D. Yang was particularly applicable, and we eventually chose $\operatorname{Pd}_{2}(\mathrm{dba})_{3}$ as our standard source of palladium. ${ }^{12}$ Optimization of the microwave system revealed that reactions could be effectively carried out at $150{ }^{\circ} \mathrm{C}$ in 10 minutes with $0.2 \mathrm{~mol}^{\%}$ of $\mathrm{Pd}_{2}(\mathrm{dba})_{3}$ and $0.4 \mathrm{~mol} \%$ of the ligand. Reactions carried out at $200{ }^{\circ} \mathrm{C}$ for only 1 minute afforded $85 \%$ of the desired product. For convenience we settled on a reaction time of 10 minutes and a temperature of $200{ }^{\circ} \mathrm{C}$ (reactions of other substrates at $150{ }^{\circ} \mathrm{C}$ resulted in slightly lower yields when compared to the corresponding reaction at $200{ }^{\circ} \mathrm{C}$ ). Using our optimized conditions, we went on to screen a range of substrates, and were delighted to find that excellent yields of the corresponding styrenes and $\alpha, \beta$-unsaturated esters could be achieved in reaction times of only 10 minutes (Table 1 ). We have observed that the reactions are tolerant of both electron-donating and withdrawing substituents on either the aryl iodide or the alkene components, with yields generally of over $95 \%$. Although these reactions were carried out under microwave irradiation, we also confirmed that these reactions can take place under more conventional thermal conditions. The Heck reaction of butyl acrylate and iodobenzene achieved complete conversion within two hours using standard reflux conditions. Excellent yield of the $\alpha, \beta$-unsaturated ester was achieved $(98 \%)$ with a similar level of purity $(>90 \%)$.

Table 1. Heck reaction using palladium and ligand $9 .^{a}$

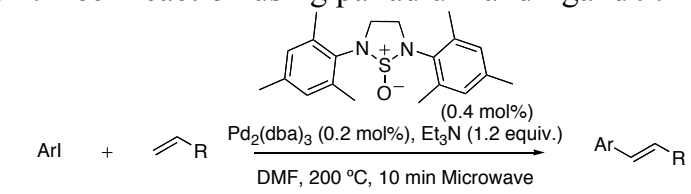

Aryl
Iodide

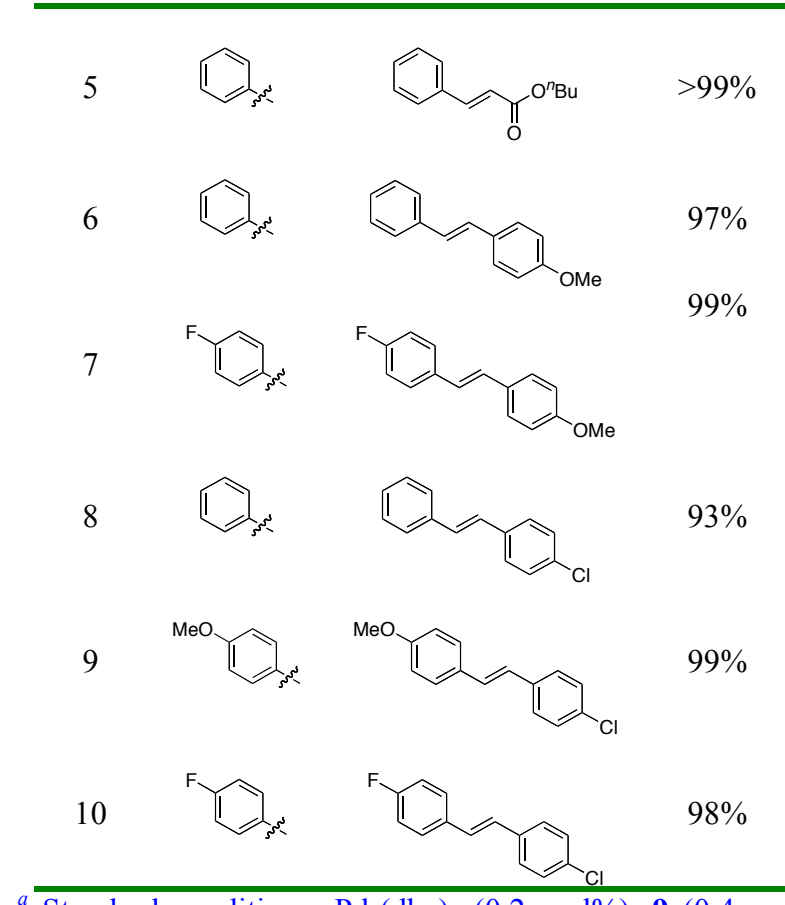

a Standard conditions: $\mathrm{Pd}_{2}(\mathrm{dba})_{3}(0.2 \mathrm{~mol} \%), 9(0.4 \mathrm{~mol} \%)$, $\mathrm{Et}_{3} \mathrm{~N}$ (1.2 equiv.), DMF $(0.5 \mathrm{~mL}), 200{ }^{\circ} \mathrm{C}, 10 \mathrm{~min}$ in a Biotage Initiator Microwave. ${ }^{b}$ Yield of isolated product over an average of 3 runs.

For convenience, stock catalyst solutions of the palladium/ligand complex were prepared and we were surprised to find that the prepared ligand/palladium complex is extremely air and moisture tolerant and can be stored for months as a stock solution in DMF or NMP open to air at room temperature with no observable loss of activity (a similar oservation for thiourea systems has been reported by D. Yang $\left.{ }^{12}\right){ }^{22}$ This is in stark contrast to a range of phosphine ligands that have to be prepared and used under strict inert reaction conditions and, therefore, precludes their effective use in industrial applications.

\subsection{Synthesis of new ligands}

With our optimized conditions in hand we moved on to examine a range of ligands in the Mizoroki-Heck reaction. The commercial availability of some $N, N^{\prime}$-substituted ethylenediamines allowed for simple preparation of phenyl- and benzyl- substituted ligands $\mathbf{1 1}$ and $\mathbf{1 2}$ in a single step by treatment with thionyl chloride and triethylamine (Scheme 2).

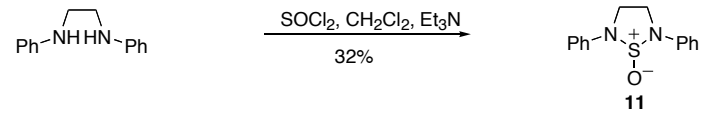

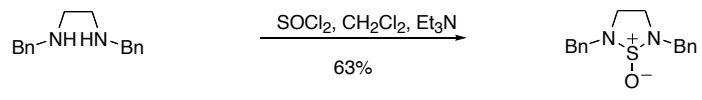

$$
\begin{aligned}
& 12
\end{aligned}
$$

Scheme 2. Synthesis of the thiadiazolidine oxides $\mathbf{1 1}$ and $\mathbf{1 2}$ from commercial diamines.

The preparation of an $o$-tolyl substituted thiadiazolidine oxide 13, however, did not proceed under the same solvent conditions as previously employed; the use of dichloromethane instead of diethyl ether as solvent was required for the thionyl chloride reaction to be successful. However, for reasons as yet unclear this compound is unstable and when left at room temperature it reverts back to the bis-amine precursor over a period of a week (Scheme 3). 


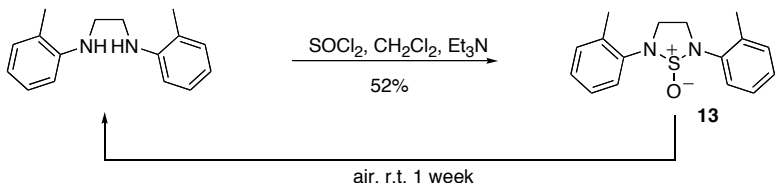

Scheme 3. Synthesis of the thiadiazolidine oxides $\mathbf{1 3}$ and its decomposition back to the diamine

The (2,6-diisopropylphenyl)- substituted ligand $\mathbf{1 4}$ was prepared using a similar route to the original mesityl substituted ligand, differing only in the choice of reducing agent to convert the bis-imine to its bis-amine $\mathbf{1 5}$ counterpart, as $\mathrm{NaBH}_{4}$ proved ineffective, $\mathrm{LiAlH}_{4}$ was used (Scheme 4). The (4methoxyphenyl)- analogue $\mathbf{1 6}$ was synthesized in the same manner as the original mesityl substituted ligand (Scheme 5).

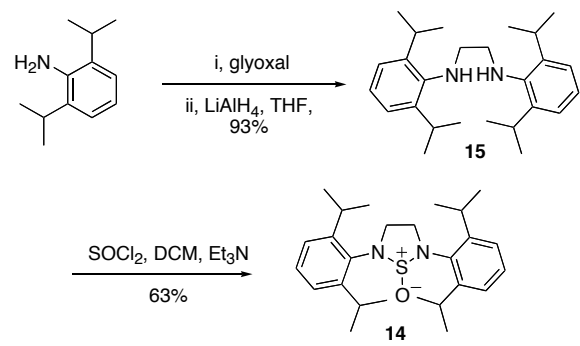

Scheme 4. Synthesis of the thiadiazolidine oxide 14

$$
\frac{\mathrm{SOCl}_{2}, \mathrm{DCM}, \mathrm{Et}_{3} \mathrm{~N}}{92 \%}
$$

Scheme 5. Synthesis of the thiadiazolidine oxide $\mathbf{1 6}$

In some cases the preparation of substituted bis-amine precursors proved difficult as the bis-imines did not form. A method of bypassing the imine formation stage was discovered by adding 2 equivalents of benzotriazole (relative to glyoxal). ${ }^{23}$ This resulted in the benzotriazole adducts 17/18 which can be easily filtered and reduced using sodium borohydride to produce the corresponding bis-amines 19/20 (Scheme 6).

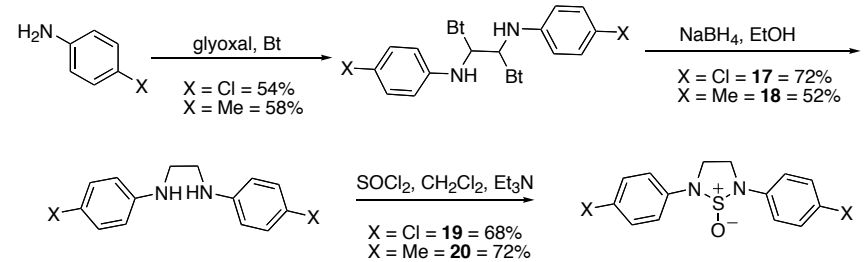

Scheme 6. Synthesis of the thiadiazolidine oxides $\mathbf{1 9}$ and $\mathbf{2 0}$ utilizing benzotriazole.

The $p$-chlorophenyl derivative $\mathbf{1 9}$ is unstable when stored at room temperature, like the $o$-tolyl derivative 13, degrading within a matter a days to its bis-amine precursor. Electron withdrawing groups as aromatic substituents in these structures is unfavourable for thiodiazolidine oxide synthesis and stability. This is exemplified by the failure to produce any other ligands with electron withdrawing groups on the aryl ring. For example, the syntheses of the $p$-nitrile and $p$-nitro analogues were unsucessful.

\subsection{Application in catalysis}

With the new ligands available we chose to assess their ability in the more challenging coupling of aryl bromides, initial optimization studies using ligand 9 are shown in Table 2. The conditions used for aryl iodides were found to be unsuitable for aryl bromides. The solvent was changed from DMF to $\mathrm{N}$ methylpyrrolidinone (NMP), and sodium acetate was used as the base and TBAB was added. The synthesis of various stilbene products with both electron-donating and -withdrawing groups was possible affording the desired products in good to excellent yields.

Table 2. Heck reaction using palladium and ligand $9 .{ }^{a}$

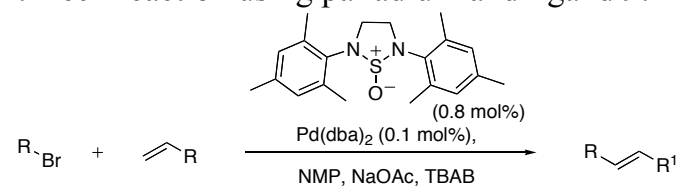

Entry

${ }^{a}$ Standard conditions: $\mathrm{Pd}(\mathrm{dba})_{2}(0.1 \mathrm{~mol} \%), 9$ (0.8 $\left.\mathrm{mol} \%\right)$, $\mathrm{NaOAc}\left(1.5\right.$ equiv.), NMP $(0.5 \mathrm{~mL})$, TBAB $(0.4$ equiv. $), 200^{\circ} \mathrm{C}$, $30 \mathrm{~min}$, in a Biotage Initiator Microwave. ${ }^{b}$ Yield of isolated product.

The Heck reaction of bromobenzene and butyl acrylate was chosen as a test reaction to demonstrate the relative reactivity of each ligand. Stock solutions of the ligands were prepared, using undried solvent and stirred openly in air, to maintain consistency. Different stock solutions took on different colours, varying from yellow, to red and dark brown. Aside from entries 2 and 8 all of the ligands performed well in the reaction with the benzyl substituted system and the 4-chloro system producing the best results (Table 3 ). Unfortunately as it stands, no correlation has been observed in terms of steric bulk or electronics of the $N$ substituents towards reactivity of the catalysts.

Table 3. Heck reactions using a range of ligands. ${ }^{a}$

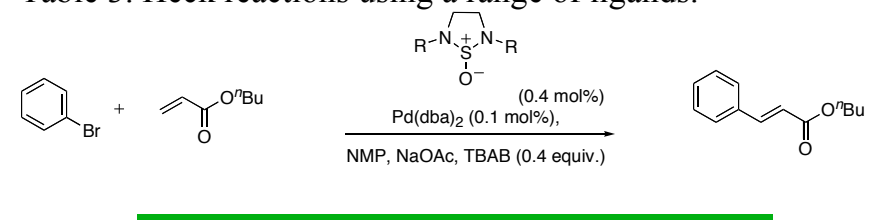

Entry Ligand




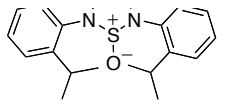

6

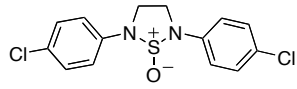

7

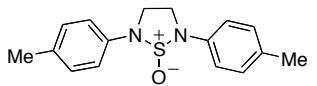

8

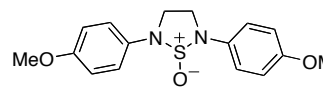

$94 \%$

$82 \%$

$19 \%$
${ }^{a}$ Standard conditions: $\mathrm{Pd}(\mathrm{dba})_{2}(0.1 \mathrm{~mol} \%)$, Ligand $(0.4$ mol\%), NaOAc (1.5 equiv.), NMP (0.5 mL), TBAB (0.4 equiv.), $200{ }^{\circ} \mathrm{C}, 30 \mathrm{~min}$, in a Biotage Initiator Microwave. ${ }^{b}$ Yield of isolated product.

After successful conversion of the aryl bromides and iodides to stilbene products we turned our attention to the effectiveness of this ligand system over a range of catalyst loadings (Table 4). Our experiments have shown that the system was still effective at extremely low catalyst loadings; for lower loadings the reaction times could be extended to give conversions $>95 \%$ (aryl iodides). After some optimization it appears that we can achieve highly effective conversions to the stilbenes from 4-iodoanisole (98\%) and 4-bromoanisole (79\%) with as little as $0.0002 \mathrm{~mol} \%$ palladium and $0.0004 / 0.0008 \mathrm{~mol} \%$ of the ligand (TON of 490000 and 740000 respectively). Although low conversions can be somewhat increased by irradiating for a second or third time in the microwave reactor, it is far more effective to irradiate the reaction mixture for a longer single run.

Table 4 . Heck reactions using a range of ligands. ${ }^{a}$

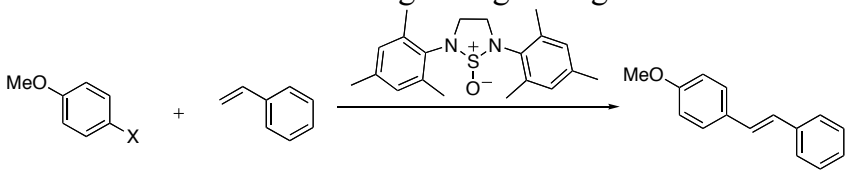

$\begin{array}{ccccccc}\text { Entry } & \mathrm{X} & \begin{array}{c}\mathrm{Pd} \\ (\mathrm{mol} \%)\end{array} & \begin{array}{c}\mathbf{9} \\ (\mathrm{mol} \%)\end{array} & \begin{array}{c}\text { Time } \\ (\mathrm{min})\end{array} & \text { TON } & \begin{array}{c}\text { Conv. } \\ (\%)^{b}\end{array}\end{array}$

\begin{tabular}{ccccccc}
\hline 1 & $\mathrm{I}$ & 0.2 & 0.4 & 10 & 485 & $97 \%$ \\
2 & $\mathrm{I}$ & 0.02 & 0.04 & 10 & 5000 & $100 \%$ \\
3 & $\mathrm{I}$ & 0.002 & 0.004 & 10 & 29000 & $58 \%$ \\
4 & $\mathrm{I}$ & 0.002 & 0.004 & 30 & 48500 & $97 \%$ \\
5 & $\mathrm{I}$ & 0.0002 & 0.0004 & 10 & 160000 & $32 \%$ \\
6 & $\mathrm{I}$ & 0.0002 & 0.0004 & 30 & 205000 & $41 \%$ \\
7 & $\mathrm{I}$ & 0.0002 & 0.0004 & 60 & 490000 & $98 \%$ \\
8 & $\mathrm{I}$ & 0.00002 & 0.00004 & 30 & 1050000 & $21 \%$ \\
9 & $\mathrm{Br}$ & 0.0001 & 0.0008 & 30 & 600000 & $60 \%$ \\
10 & $\mathrm{Br}$ & 0.0001 & 0.0008 & 60 & 640000 & $64 \%$ \\
11 & $\mathrm{Br}$ & 0.0001 & 0.0008 & 120 & 740000 & $74 \%$ \\
\hline
\end{tabular}

${ }^{a}$ Standard conditions for aryl iodides: $\mathrm{Pd}_{2}(\mathrm{dba})_{3}, 9, \mathrm{Et}_{3} \mathrm{~N}(1.2$ equiv.), DMF $(0.5 \mathrm{~mL}), 200{ }^{\circ} \mathrm{C}$, in a Biotage Initiator Microwave; Standard conditions for aryl bromides: $\mathrm{Pd}(\mathrm{dba})_{2}(0.1$ mol\%), 9 (0.8 mol\%), NaOAc (1.5 equiv.), NMP (0.5 mL), TBAB ( 0.4 equiv.), $200{ }^{\circ} \mathrm{C} .{ }^{b}$ Conversions were evaluated using
${ }^{1} \mathrm{H}-\mathrm{NMR}$ spectroscopy, by comparison of the methylene protons from 4-iodoanisole or 4-bromoanisole and the product.

The activity of our system appears to be highly dependent on the presence of anionic ligands for palladium, like halide or acetate ions. The "halide effect" has been thoroughly studied by, for example, Amatore and Jutand. ${ }^{24}$ Computational studies of the effects of halides or acetates have been published by Shaik ${ }^{25}$ and by Norrby. ${ }^{26}$ Some very interesting results showing high activity of palladium in the presence of acetate anions were published by Reetz ${ }^{27}$ and by de Vries. ${ }^{28}$ In view of these reports, we decided to run the same experiments in the absence of any ligand, as it is plausible that the active palladium species does not contain the ligand. However, when using $1.0 \mathrm{~mol} \% \mathrm{Pd}$ systems for the conversion of aryl iodides and aryl bromides in the absence of ligand 9 we observed a maximum of up to $40 \%$ conversion to the desired Heck product (compared to $76 \%$ conversion when using ligand 9). Indicating that the active catalytic species must require the ligand for high turnover and product yield. At lower catalyst loadings the results become somewhat more complicated as reported by Reetz and by de Vries high yields of styrene products can be produced with stabilized nanoparticles. In order to rule out these nanopartculate species we carried out additional experiments using the mercury drop technique. Addition of mercury to palladium catalysed reactions has been shown to remove the catalytic activity of any heterogeneous species. ${ }^{34}$ Under our reaction conditions for the Heck reaction of aryl bromides using ligand 9 we observed the same level of conversion to the stilbene products under both mercury free and mercury added experiments at very low palladium loadings $(0.0001 \mathrm{~mol} \%)$. Although this does rule out the possibility of heterogeneous nanoparticulates catalyzing the reaction there is still the effect of the dba ligand to be explored as reported by Fairlamb and co-workers. ${ }^{35}$

\section{Conclusion}

In summary, we have developed a series of highly active, easily prepared and air-stable thiadiazolidine 1-oxide ligands, which in conjunction with palladium effectively catalyse the Mizoroki-Heck reaction of activated and unactivated iodides and bromides. Remarkably, the prepared ligand/palladium complexes can be stored (months) as a stock solution in DMF or NMP open to air at room temperature with no observable loss of activity.

\section{Experimental}

\subsection{General Remarks}

All infrared spectra were obtained using a Perkin-Elmer Paragon 1000 FT-IR spectrophotometer; thin film spectra were acquired using sodium chloride plates. All ${ }^{1} \mathrm{H}$ and ${ }^{13} \mathrm{C}$ NMR spectra were measured at 400.13 and $100.62 \mathrm{MHz}$ with a Bruker DPX 400 $\mathrm{MHz}$ spectrometer, in deuteriochloroform solution unless otherwise stated, using TMS (tetramethylsilane) as the internal reference. Mass spectra were recorded using a Jeol-SX102 instrument utilizing electron-impact (EI), fast atom bombardment (FAB). Melting points were recorded using an Electrothermal-IA 9100 melting point instrument and are uncorrected. Microanalyses were performed on a Perkin Elmer Elemental Analyser 2400 CHN. All chromatographic manipulations used silica gel as the adsorbent. Reactions were monitored using thin layer chromatography (TLC) on aluminium-backed plates coated with Merck Kieselgel 60 F254 silica gel. TLC plates were visualized by UV radiation at a wavelength of $254 \mathrm{~nm}$, or stained by exposure to an ethanolic solution of phosphomolybdic acid (acidified with concentrated sulfuric acid), followed by charring where appropriate. Reaction solvents were used as obtained 
commercially unless otherwise stated. Light petroleum (b.p. 40$60{ }^{\circ} \mathrm{C}$ ) was distilled from calcium chloride prior to use. Ethyl acetate was distilled over calcium sulfate or chloride. Dichloromethane was distilled over calcium hydride.

\subsection{Synthesis of 2,5-di(2,4,6-trimethylphenyl)-1,2,5-} thiadiazolidine-1-oxide (9): Mesityl amine $(5.0 \mathrm{~g}, 37.0 \mathrm{mmol})$ was added to a stirred solution of glyoxal $(1.71 \mathrm{~g}, 18.5 \mathrm{mmol}$ $40 \%$ solu. in $\mathrm{H}_{2} \mathrm{O}$ ) after 30 min a bright yellow solid precipitated (bis-imine). Dichloromethane $(50 \mathrm{~mL})$ was added to dissolve the mixture followed by ethanol $(50 \mathrm{~mL})$ this was then followed by portion-wise addition of sodium borohydride (5.6 g, 148.0 mmol). The reaction was left to stir overnight at room temperature and the colourless solution quenched by addition of conc. hydrochloric acid $(0.5 \mathrm{~mL})$ quickly followed by the addition of water $(50 \mathrm{~mL})$. The ethanol was evaporated under reduced pressure, and the aqueous solution was extracted with ethyl acetate $(3 \times 50 \mathrm{ml})$ and dried with $\mathrm{MgSO}_{4}$. Evaporation of the organics under reduced pressure afforded product $\mathbf{1 0}$ as a colourless oil which was used directly in the next step $(5.1 \mathrm{~g}$, 93\%). ${ }^{1} \mathrm{H}-\mathrm{NMR}\left(400 \mathrm{MHz}, \mathrm{CDCl}_{3}\right) 2.23(6 \mathrm{H}, \mathrm{s}), 2.28(12 \mathrm{H}, \mathrm{s})$, $3.15(4 \mathrm{H}, \mathrm{s}), 6.82-6.83(4 \mathrm{H}, \mathrm{m}) ;{ }^{13} \mathrm{C}-\mathrm{NMR}\left(100 \mathrm{MHz}, \mathrm{CDCl}_{3}\right)$ $18.4,20.6,49.2,129.2,129.8,131.5,143.4$. A solution of $\mathbf{1 0}(5.0$ $\mathrm{g}, 16.9 \mathrm{mmol})$ in diethylether $(100 \mathrm{~mL})$ and triethylamine $(5.2$ $\mathrm{mL}, 37.2 \mathrm{mmol})$ was treated with with thionyl chloride $(1.2 \mathrm{~mL}$, $16.9 \mathrm{mmol}$ ) by dropwise addition at $0{ }^{\circ} \mathrm{C}$ and stirred for $12 \mathrm{~h}$ whilst attaining ambient temperature. Filtration of the triethylamine hydrochloride and evaporation under reduced pressure afforded the thiadiazolidine-1-oxide 9. Recrystallization from dichlormethane/diethyl ether afforded colourless crystals $(4.8 \mathrm{~g}, 83 \%) . v_{\max }($ film $) / \mathrm{cm}^{-1} 3462,2917,2865,1607,1481$, $1375,1241,1123,851,735$; m.p. $133-135{ }^{\circ} \mathrm{C}$; found C, $70.23 ; \mathrm{H}$, 7.44; N, 8.01\%. $\mathrm{C}_{20} \mathrm{H}_{26} \mathrm{~N}_{2} \mathrm{SO}$ requires $\mathrm{C}, 70.14 ; \mathrm{H}, 7.65 ; \mathrm{N}$, 8.18\%; ${ }^{1} \mathrm{H}-\mathrm{NMR}\left(400 \mathrm{MHz}, \mathrm{CDCl}_{3}\right) 2.29(6 \mathrm{H}, \mathrm{s}), 2.45(12 \mathrm{H}$, m), 3.59-3.63 (2 H, m), 4.22-4.25 (2 H, m), $6.93(4 \mathrm{H}) ;{ }^{13} \mathrm{C}-\mathrm{NMR}$ $\left(100 \mathrm{MHz}, \mathrm{CDCl}_{3}, 60{ }^{\circ} \mathrm{C}\right) 18.9,20.7,51.4,129.5,134.4,137.6$, $139.0 ; \mathrm{m} / \mathrm{z} 342.1764 ; \mathrm{C}_{20} \mathrm{H}_{26} \mathrm{~N}_{2} \mathrm{SO}(\mathrm{M}+)$ requires 342.1766.

4.3 Representiaitve procedure for the formation of thiadiazolidine-1-oxides from commercially available diamines: 2,5-Diphenyl-1,2,5-thiadiazolidine-1-oxide (11): 1,2-Dianiloethane $(3.0 \mathrm{~g}, 14.1 \mathrm{mmol})$ was dissolved in diethyl ether $(100 \mathrm{~mL})$ at $0{ }^{\circ} \mathrm{C}$ followed by addition of triethylamine (4.29 mL, $30.8 \mathrm{mmol})$. Thionyl chloride $(1.02 \mathrm{~mL}, 14.1 \mathrm{mmol})$ was slowly added by syringe. After addition of the thionyl chloride the resulting mixture was warmed to room temperature and allowed to stir for 18 hours. The reaction mixture was then washed with water $(3 \times 80 \mathrm{~mL})$ and the combined organic phases dried $\left(\mathrm{MgSO}_{4}\right)$ and evaporated under reduced pressure to afford the crude product. Recrystalization from diethyl ether afforded a tan coloured solid $1.2 \mathrm{~g}, 33 \%$; m.p. $159-161{ }^{\circ} \mathrm{C} ; v_{\max }($ film $) / \mathrm{cm}^{-1}$ 1595, 1127, 745, 688; ${ }^{1} \mathrm{H}-\mathrm{NMR}\left(400 \mathrm{MHz}, \mathrm{CDCl}_{3}\right)$ 3.89-3.98 (2 $\mathrm{H}, \mathrm{m}), 4.18-4.28(2 \mathrm{H}, \mathrm{m}), 7.08(2 \mathrm{H}, \mathrm{t}, J=12 \mathrm{~Hz}), 7.17(4 \mathrm{H}, \mathrm{d}, J$ $=10 \mathrm{~Hz}) 7.36(4 \mathrm{H}, \mathrm{t}, J=8 \mathrm{~Hz}) ;{ }^{13} \mathrm{C}-\mathrm{NMR}\left(100 \mathrm{MHz}, \mathrm{CDCl}_{3}\right)$ 47.4, 117.4, 123.0, 129.5, 141.3; m/z 259.0909 $\mathrm{C}_{14} \mathrm{H}_{14} \mathrm{~N}_{2} \mathrm{SO}$ $(\mathrm{M}+\mathrm{H})$ requires 259.0905 .

4.3.1 Synthesis of 2,5-Dibenzyl-1,2,5-thiadiazolidine-1-oxide (12): Prepared according to the representative procedure from $N, N$-Dibenzylethylenediamine $(2.94 \mathrm{~mL}, 12.5 \mathrm{mmol})$. Light brown oil which crystallized on standing, 2.1 g, 59\%; m.p. 62-65 ${ }^{\circ} \mathrm{C} ; v_{\max }\left(\right.$ film) $/ \mathrm{cm}^{-1} 3028,2865,1652,1494,1455,1362,1311$, 1107, 930, 698; ${ }^{1} \mathrm{H}-\mathrm{NMR}\left(400 \mathrm{MHz}, \mathrm{CDCl}_{3}\right)$ 3.09-3.18 (2 H, m), 3.35-3.44 (2 H, m), $4.05(2 \mathrm{H}, \mathrm{d}, J=14 \mathrm{~Hz}), 4.25(2 \mathrm{H}, \mathrm{d}, J=14$ $\mathrm{Hz})$ 7.22-7.36 (10 H, m); ${ }^{13} \mathrm{C}-\mathrm{NMR}\left(100 \mathrm{MHz}, \mathrm{CDCl}_{3}\right) 49.9,52.3$, $127.8,128.4,136.5 ; m / z 287.1221 \mathrm{C}_{16} \mathrm{H}_{18} \mathrm{~N}_{2} \mathrm{SO}(\mathrm{M}+\mathrm{H})$ requires 287.1218 .
4.3.2 Synthesis of 2,5-Di(o-tolyl)-1,2,5-thiadiazolidine-1-oxide (13): Prepared according to the representative procedure from $N, N$-di(o-tolyl)ethylenediamine $(1.5 \mathrm{~g}, 6.2 \mathrm{mmol})$. Recrystalized from diethyl ether, tan coloured solid, $0.82 \mathrm{~g}, 46 \%$; m.p. $90-92$ ${ }^{\circ} \mathrm{C} ; v_{\max }($ film $) / \mathrm{cm}^{-1} 3019,2950,2868,1598,1580,1488,1458$, 1246, 1192, 1126, 1045, 977, 908, 840, 787, 761, 721, 656, 610; ${ }^{1} \mathrm{H}-\mathrm{NMR}\left(400 \mathrm{MHz}, \mathrm{CDCl}_{3}\right) 2.43(6 \mathrm{H}, \mathrm{s}), 3.64-3.67$ (2 H, m), 4.22-4.26 (2 H, m), 7.14-7.25 (6 H, m), 7.31-7.33 (2 H, m); ${ }^{13} \mathrm{C}-$ NMR $\left(100 \mathrm{MHz}, \mathrm{CDCl}_{3}\right)$ 18.6, 51.7, 126.4, 127.0, 127.1, 131.2, $136.4,139.6 ; m / z 287.1211 \mathrm{C}_{16} \mathrm{H}_{18} \mathrm{~N}_{2} \mathrm{SO}(\mathrm{M}+\mathrm{H})$ requires 287.1218 .

4.4 Synthesis of 2,5-di(2,6-diisopropylphenyl)-1,2,5thiadiazolidine-1-oxide (14): 2,6-Diisopropylaniline $(3.0 \mathrm{~mL}$, $24.0 \mathrm{mmol})$ and glyoxal $\left(1.74 \mathrm{~g}, 12.0 \mathrm{mmol}, 40 \%\right.$ solu. in $\left.\mathrm{H}_{2} \mathrm{O}\right)$ were dissolved in methanol $(40 \mathrm{~mL})$. A few drops of formic acid were added and the resulting solution was allowed to stir at room temperature for 1 hour. The precipitate was filtered under vacuum and washed with methanol to afford a bright yellow solid (0.95 g, $2.5 \mathrm{mmol}, 21 \%) ; v_{\max }($ film $) / \mathrm{cm}^{-1} 3060,2960,2869,1626$, $1455,1431,1360,1174,1042,921,817,793,757$; ${ }^{1} \mathrm{H}-\mathrm{NMR}(400$ $\left.\mathrm{MHz}, \mathrm{CDCl}_{3}\right) 1.23(24 \mathrm{H}, \mathrm{d}, J=7 \mathrm{~Hz}), 2.97$ (4 H, sep) $7.21(6 \mathrm{H}$, m), $8.13(2 \mathrm{H}, \mathrm{s}) ;{ }^{13} \mathrm{C}-\mathrm{NMR}\left(100 \mathrm{MHz}, \mathrm{CDCl}_{3}\right)$ 23.4, 28.1, 123.1, $125.1,136.7,148.0,163.1$. The crude product from above $(0.95$ $\mathrm{g}, 2.5 \mathrm{mmol}$ ) was placed in a three necked round bottomed flask and dissolved in dry THF $(50 \mathrm{~mL})$ under a nitrogen atmosphere. $\mathrm{LiAlH}_{4}$ in THF solution $(1.5 \mathrm{~mL}, 2.0 \mathrm{M})$ was carefully added via syringe and allowed to stir at room temperature for 3 hours by which time the solution had turned white. The reaction was quenched with aqueous sodium potassium tartrate and extracted with dichloromethane ( $3 \times 40 \mathrm{~mL})$. Solvents were removed under reduced pressure to afford a colourless solid $(0.62 \mathrm{~g}, 1.63 \mathrm{mmol}$, $65 \%) ; v \max ($ film $) / \mathrm{cm}^{-1} 3367,2957,2864,1587,1456,1441$, 1383, 1330, 1248, 1230, 1196, 1111, 1084, 944, 909, 798, 752; ${ }^{1} \mathrm{H}-\mathrm{NMR}\left(400 \mathrm{MHz}, \mathrm{CDCl}_{3}\right) 1.26(24 \mathrm{H}, \mathrm{d}, J=7 \mathrm{~Hz}), 3.16(4 \mathrm{H}$, s), $3.36(4 \mathrm{H}$, sep, $J=7 \mathrm{~Hz}), 7.07(6 \mathrm{H}, \mathrm{m}),{ }^{13} \mathrm{C}-\mathrm{NMR}(100 \mathrm{MHz}$, $\left.\mathrm{CDCl}_{3}\right)$ 24.2, 27.7, 52.3, 123.6, 123.8, 142.4, 143.3. N, N'Bis(2,6-diisopropylphenyl)ethylenediamine $(0.62 \mathrm{~g}, 1.63 \mathrm{mmol})$ was dissolved in dichloromethane $(50 \mathrm{~mL})$ at $0{ }^{\circ} \mathrm{C}$ followed by addition of triethylamine $(0.59 \mathrm{~mL}, 4.2 \mathrm{mmol})$. Thionyl chloride $(0.14 \mathrm{~mL}, 1.63 \mathrm{mmol})$ was then slowly added by syringe. the resulting mixture was warmed to room temperature and allowed to stir for 18 hours. The reaction mixture was then washed with water $(3 \times 80 \mathrm{~mL})$ and the combined organic phases dried $\left(\mathrm{MgSO}_{4}\right)$ and evaporated under reduced pressure to afford the crude product. Recrystalization from diethyl ether afforded colourless crystals $\left(0.42\right.$ g, 60\%); m.p. $185-188{ }^{\circ} \mathrm{C}$; $v_{\max }($ film $) / \mathrm{cm}^{-1} 2958,2864,1607,1584,1444,1323,1263,1208$, $1183,1129,1063,805,734 ;{ }^{1} \mathrm{H}-\mathrm{NMR}\left(400 \mathrm{MHz}, \mathrm{CDCl}_{3}\right) 1.25-$ $1.29(24 \mathrm{H}, \mathrm{m}), 3.41(2 \mathrm{H}$, sep., $J=7 \mathrm{~Hz}), 3.63-3.67(2 \mathrm{H}, \mathrm{m})$, $3.81(2 \mathrm{H}$, sep., $J=7 \mathrm{~Hz}), 4.19-4.23(2 \mathrm{H}, \mathrm{m}), 7.19(1 \mathrm{H}, \mathrm{d}, J=$ $1.6 \mathrm{~Hz}), 7.21(1 \mathrm{H}, \mathrm{d}, J=2 \mathrm{~Hz}), 7.23(1 \mathrm{H}, \mathrm{d}, J=2 \mathrm{~Hz}), 7.25$ (1 $\mathrm{H}, \mathrm{d}, J=2 \mathrm{~Hz}), 7.33(2 \mathrm{H}, \mathrm{t}, J=8 \mathrm{~Hz}) ;{ }^{13} \mathrm{C}-\mathrm{NMR}(100 \mathrm{MHz}$, $\left.\mathrm{CDCl}_{3}\right)$ 24.3, 24.7, 24.9, 25.1, 28.5, 28.8, 54.3, 123.9, 124.6, $128.8,134.2,149.2,151.1 ; m / z \quad 427.2775 ; \mathrm{C}_{26} \mathrm{H}_{38} \mathrm{~N}_{2} \mathrm{SO}(\mathrm{M}+\mathrm{H})$ requires 427.2783 .

4.5 Synthesis of 2,5-di(4-methoxyphenyl)-1,2,5thiadiazolidine-1-oxide (16): 4-Anisidine (3.0 g, $24.4 \mathrm{mmol}$ ) and glyoxal (1.77 g, $12.2 \mathrm{mmol}, 40 \%$ solu. in $\left.\mathrm{H}_{2} \mathrm{O}\right)$ were stirred in methanol $(40 \mathrm{~mL})$ in the presence of a few drops of formic acid. After 1 hour the resulting bright yellow bis-imine precipitate was filtered and dried by vacuum filtration $(2.82 \mathrm{~g}$, $87 \%)$. The bis-imine $(1.0 \mathrm{~g}, 3.7 \mathrm{mmol})$ was dissolved in dichloromethane $(30 \mathrm{~mL})$ and $\mathrm{MeOH}(30 \mathrm{~mL}), \mathrm{NaBH}_{4}$ was gradually added until the solution became colourless. The reaction mixture was quenched with conc. $\mathrm{HCl}(0.5 \mathrm{~mL})$ and 
water $(50 \mathrm{~mL})$. The organics were extracted with dichloromethane $(3 \times 60 \mathrm{~mL})$ and dried with $\mathrm{MgSO}_{4}$. The solvent was evaporated under reduced pressure to afford a tan coloured solid (0.82g, 82\%); ${ }^{1} \mathrm{H}-\mathrm{NMR}\left(400 \mathrm{MHz} \mathrm{CDCl}_{3}\right) 3.39(4 \mathrm{H}, \mathrm{s})$ $3.75(6 \mathrm{H}, \mathrm{s}) 6.63(4 \mathrm{H}, \mathrm{d}, J=9 \mathrm{~Hz}) 6.79(4 \mathrm{H}, \mathrm{d}, J=9 \mathrm{~Hz}){ }^{13} \mathrm{C}-$ NMR $\left(100 \mathrm{MHz} \mathrm{CDCl}_{3}\right) 44.5,55.8,114.6,114.9,142.2,152.5$. A solution of $N, N$-di(4-methoxyphenyl)ethylenediamine $(0.22 \mathrm{~g}$, $0.8 \mathrm{mmol})$ in diethyl ether $(30 \mathrm{~mL})$ and triethylamine $(0.24 \mathrm{~mL}$, $1.8 \mathrm{mmol})$ was treated with thionyl chloride $(0.57 \mathrm{~mL}, 0.8 \mathrm{mmol})$ by dropwise addition at $0{ }^{\circ} \mathrm{C}$ and stirred for 12 hours whilst attaining ambient temperature. Filtration of triethylamine hydrochloride and evaporation under reduced pressure afforded the thiadiazolidine-1-oxide as a tan coloured solid $(0.23 \mathrm{~g}, 92 \%)$; m.p. $149-151^{\circ} \mathrm{C} ; v_{\max }($ film $) / \mathrm{cm}^{-1} 2947,1514,1452,1245,1125$, 1028, 823; ${ }^{1} \mathrm{H}-\mathrm{NMR}\left(400 \mathrm{MHz}, \mathrm{CDCl}_{3}\right) 3.80(6 \mathrm{H}, \mathrm{s}), 3.83-3.86$ $(2 \mathrm{H}, \mathrm{m}) 4.16-4.19(2 \mathrm{H}, \mathrm{m}), 6.91(4 \mathrm{H}, \mathrm{d}, J=9 \mathrm{~Hz}), 7.14(4 \mathrm{H}, \mathrm{d}$, $J=9 \mathrm{~Hz}){ }^{13} \mathrm{C}-\mathrm{NMR}\left(100 \mathrm{MHz} \mathrm{CDCl}_{3}\right) 48.7,55.6,114.9,120.5$, $134.5, \quad 156.3 ; \quad m / z \quad 318.1043 ; \quad \mathrm{C}_{16} \mathrm{H}_{18} \mathrm{~N}_{2} \mathrm{SO}_{3}(\mathrm{M}+)$ requires 318.1038 .

4.6 Representative procedure for the formation of thiadiazolidine-1-oxides using the benzotriazole method: Synthesis of 2,5-di(4-chlorophenyl)-1,2,5-thiadiazolidine-1oxide (19): 4-Chloroaniline (4.71 g, $36.9 \mathrm{mmol})$ and benzotriazole ( $4.3 \mathrm{~g}, 36.9 \mathrm{mmol})$ were dissolved in ethanol $(80$ $\mathrm{mL}$ ) and stirred at room temperature for 10 minutes. Glyoxal (1.7 g, $18.5 \mathrm{mmol}, 40 \%$ solu. in $\mathrm{H}_{2} \mathrm{O}$ ) was then added and stirring was continued for 18 hours. The precipitate was then filtered under vacuum to afford the benzotriazole adduct as a colourless solid (5.21 g, $10.1 \mathrm{mmol}, 55 \%)$. The solid was then dissolved in tetrahydrofuran $(80 \mathrm{~mL})$. Sodium borohydride $(1.6 \mathrm{~g}, 42.3 \mathrm{mmol})$ was added to the flask and stirred at room temperature for 18 hours. The solution was then diluted with ethyl acetate $(50 \mathrm{~mL})$, washed with water $(50 \mathrm{~mL})$ and sodium hydroxide $(50 \mathrm{~mL}, 2 \mathrm{M})$. The organic phase was dried over $\mathrm{MgSO}_{4}$ and the solvent removed under reduced pressure to afford a colourless solid. (2.04 g, $7.3 \mathrm{mmol}, 39 \%)$; ${ }^{1} \mathrm{H}-\mathrm{NMR}\left(400 \mathrm{MHz}, \mathrm{CDCl}_{3}\right) 3.31(4 \mathrm{H}$, s), $3.60-3.90(2 \mathrm{H}, \mathrm{bs}), 6.53(4 \mathrm{H}, \mathrm{d}, J=9 \mathrm{~Hz}), 7.12(4 \mathrm{H}, \mathrm{d}, J=$ $9 \mathrm{~Hz}) ;{ }^{13} \mathrm{C}-\mathrm{NMR}\left(100 \mathrm{MHz}, \mathrm{CDCl}_{3}\right) 43.3,114.1,122.4,128.9$, 146.2. $N, N^{\prime}$-Bis ( $p$-chlorophenyl)ethylenediamine $(2.12 \mathrm{~g}, 7.6$ $\mathrm{mmol})$ was dissolved in diethyl ether $(50 \mathrm{~mL})$ at $0{ }^{\circ} \mathrm{C}$ followed by addition of triethylamine $(2.31 \mathrm{~mL}, 16.6 \mathrm{mmol})$. Thionyl chloride $(0.55 \mathrm{~mL}, 7.6 \mathrm{mmol})$ was then slowly added by syringe. After addition of the thionyl chloride the resulting mixture was warmed to room temperature and allowed to stir for 18 hours. The reaction mixture was then washed with water $(3 \times 80 \mathrm{~mL})$ and the combined organic phases dried $\left(\mathrm{MgSO}_{4}\right)$ and evaporated under reduced pressure to afford the crude product. Recrystalization from diethyl ether afforded a pale green solid, 1.76 g, 72\%; m.p. $85-87{ }^{\circ} \mathrm{C}$; $v_{\max }($ film $) / \mathrm{cm}^{-1} 2873,1593,1490$, $1261,1124,1095,814,721,611 ;{ }^{1} \mathrm{H}-\mathrm{NMR}\left(400 \mathrm{MHz}, \mathrm{CDCl}_{3}\right)$ $3.76-3.83(2 \mathrm{H}, \mathrm{m}), 4.04-4.10(2 \mathrm{H}, \mathrm{m}), 7.03(4 \mathrm{H}, \mathrm{d}, J=9 \mathrm{~Hz})$, $7.28(4 \mathrm{H}, \mathrm{d}, J=9 \mathrm{~Hz}) ;{ }^{13} \mathrm{C}-\mathrm{NMR}\left(100 \mathrm{MHz}, \mathrm{CDCl}_{3}\right) 47.6,118.7$, $128.9,129.8,139.7$. Compound unstable, accurate mass only showed SM

4.6.1 Synthesis of 2,5-di(p-tolyl)-1,2,5-thiadiazolidine-1-oxide (20): Prepared according to the representative procedure from 4toluidine ( $4.0 \mathrm{~g}, 37.3 \mathrm{mmol})$. Recrystalization from diethyl ether afforded a tan coloured solid, 0.86 g, 54\%; m.p. 146-148 ${ }^{\circ} \mathrm{C}$; $v_{\max }($ film $) / \mathrm{cm}^{-1} 2865,2447,1616,1511,1457,1255,1127,1074$, 901, 807, 748; ${ }^{1} \mathrm{H}-\mathrm{NMR}\left(400 \mathrm{MHz}, \mathrm{CDCl}_{3}\right) 2.29$ (6 H, s), 3.81$3.85(2 \mathrm{H}, \mathrm{m}), 4.12-4.15(2 \mathrm{H}, \mathrm{m}), 7.05(4 \mathrm{H}, \mathrm{d}, J=8 \mathrm{~Hz}), 7.14$ (4 $\mathrm{H}, \mathrm{d}, J=8 \mathrm{~Hz}) ;{ }^{13} \mathrm{C}-\mathrm{NMR}\left(100 \mathrm{MHz}, \mathrm{CDCl}_{3}\right)$ 20.7, 47.7, 118.0, 130.2 , 132.7, 138.9; $m / z 287.1211 \mathrm{C}_{16} \mathrm{H}_{18} \mathrm{~N}_{2} \mathrm{SO}(\mathrm{M}+\mathrm{H})$ requires 287.1218 .
4.7 General procedure for the Mizoroki-Heck reaction using aryl iodides: $\mathrm{Pd}_{2}(\mathrm{dba})_{3}(2.3 \mathrm{mg}, 0.0025 \mathrm{mmol})$ and 9 (4 equiv) were stirred in DMF $(0.5 \mathrm{~mL})$ for $0.5 \mathrm{~h}$ at $\mathrm{rt}$. Iodobenzene $(0.28$ $\mathrm{mL}, 2.5 \mathrm{mmol}$, substrate/catalyst ratio $=500: 1)$ and styrene $(0.32$ $\mathrm{g}, 3.0 \mathrm{mmol})$ and triethylamine $(0.42 \mathrm{~mL}, 3.0 \mathrm{mmol})$ were then added. The flask was crimped and heated at $200{ }^{\circ} \mathrm{C}$ under microwave irradiation for 10 minutes. After the indicated time, the solution was diluted with ethyl acetate $(20 \mathrm{~mL})$ and washed with water and brine. Ethyl acetate was removed under reduced pressure and the product isolated by crystallization from dichloromethane/diethyl ether or by flash column chromatography.

4.8 General procedure for the Mizoroki-Heck reaction using aryl bromides: $\mathrm{Pd}(\mathrm{dba})_{2}(1.5 \mathrm{mg}, 0.0025 \mathrm{mmol})$, ligand $(8$ equiv), TBAB $(1 \mathrm{mmol})$ and sodium acetate $(0.33 \mathrm{~g}, 3.8 \mathrm{mmol}$ were stirred in NMP $(1.5 \mathrm{~mL})$ for $1 \mathrm{~h}$ at rt. Aryl bromide $(2.5$ $\mathrm{mmol}$, substrate/catalyst ratio $=1000: 1)$ and olefin $(2.5 \mathrm{mmol})$ were then added. The flask was crimped and heated at $200{ }^{\circ} \mathrm{C}$ under microwave irradiation for 30 minutes. After the indicated time, the solution was diluted with ethyl acetate $(20 \mathrm{~mL})$ and washed with water and brine. Ethyl acetate was removed under reduced pressure. The product was isolated by flash column chromatography.

\subsection{Heck Product Data:}

4.9.1 Trans-stilbene: $:^{29} v_{\max }($ film $) / \mathrm{cm}^{-1} 3077,3020,1597,1495$, 1108, 1072, 962, 764, 692; ${ }^{1} \mathrm{H}-\mathrm{NMR}\left(400 \mathrm{MHz}, \mathrm{CDCl}_{3}\right) 7.09$ (2 $\mathrm{H}, \mathrm{s}), 7.23(2 \mathrm{H}, \mathrm{t}, J=8 \mathrm{~Hz}), 7.33(4 \mathrm{H}, \mathrm{t}, J=8 \mathrm{~Hz}), 7.50(4 \mathrm{H}$, $\mathrm{m}) ;{ }^{13} \mathrm{C}-\mathrm{NMR}\left(100 \mathrm{MHz}, \mathrm{CDCl}_{3}\right)$ 126.7, 127.7, 128.9, 137.3.

4.9.2 Trans-4-methylstilbene: ${ }^{29} \quad v_{\max }(\mathrm{film}) / \mathrm{cm}^{-1} \quad 3025, \quad 2924$, $1655,1601,1448,1265,1109,966,808,737,701 ;{ }^{1} \mathrm{H}-\mathrm{NMR}(400$ $\left.\mathrm{MHz} \mathrm{CDCl}_{3}\right) 2.34(3 \mathrm{H}, \mathrm{s}) 7.02(2 \mathrm{H}, \mathrm{d}, J=3 \mathrm{~Hz}) 7.13(2 \mathrm{H}, \mathrm{d}, J$ $=8 \mathrm{~Hz}) 7.22(1 \mathrm{H}, \mathrm{t}, J=6 \mathrm{~Hz}) 7.33(2 \mathrm{H}, \mathrm{t}, J=8 \mathrm{~Hz}) 7.39(2 \mathrm{H}$, $\mathrm{d}, J=8 \mathrm{~Hz}) 7.48(2 \mathrm{H}, \mathrm{d}, J=8 \mathrm{~Hz}) ;{ }^{13} \mathrm{C}-\mathrm{NMR}(100 \mathrm{MHz}$, $\left.\mathrm{CDCl}_{3}\right) 21.3,126.5,126.6,127.5,127.8,128.7,128.8,129.5$, 134.7, 137.5, 137.6.

4.9.3 Trans-4-methoxystilbene: ${ }^{29} v_{\max }($ film $) / \mathrm{cm}^{-1} 2961,2836$, $1602,1512,1446,1254,1112,1031,966,827,812,750,689 ;{ }^{1} \mathrm{H}$ NMR (400 MHz, $\left.\mathrm{CDCl}_{3}\right) 3.88(3 \mathrm{H}, \mathrm{s}), 6.98(2 \mathrm{H}, \mathrm{d}, J=8 \mathrm{~Hz})$, $7.10(1 \mathrm{H}, \mathrm{d}, J=12 \mathrm{~Hz}), 7.33(1 \mathrm{H}, \mathrm{d}, J=12 \mathrm{~Hz}), 7.45-7.40$ (3 $\mathrm{H}, \mathrm{m}), 7.64-7.52(4 \mathrm{H}, \mathrm{m}) ;{ }^{13} \mathrm{C}-\mathrm{NMR}\left(100 \mathrm{MHz}, \mathrm{CDCl}_{3}\right) 55.3$, 116.3, 126.2, 126.6, 127.2, 128.1, 128.6 130.1, 137.6, 159.3. 4.9.4 1-Chloro-3-I(E)-2-(4-fluorophenyl)vinyl]benzene: ${ }^{30}$ $v_{\max }($ film $) / \mathrm{cm}^{-1} 3051,2924,1657,1600,1508,1417,1232,1097$, 968, 834; ${ }^{1} \mathrm{H}-\mathrm{NMR}\left(400 \mathrm{MHz} \mathrm{CDCl}_{3}\right) 6.98(1 \mathrm{H}, \mathrm{d}, J=16 \mathrm{~Hz})$ 7.04-7.09 (3 H, m), $7.35(2 \mathrm{H}, \mathrm{d}, J=9 \mathrm{~Hz}), 7.44(2 \mathrm{H}, \mathrm{d}, J=8.4$ $\mathrm{Hz}), 7.47-7.51(2 \mathrm{H}, \mathrm{m}) ;{ }^{13} \mathrm{C}-\mathrm{NMR}\left(100 \mathrm{MHz}, \mathrm{CDCl}_{3}\right)$ 115.6, 115.8, 127.1, 127.2, 127.6, 128.1, 133.1, 133.2, 135.7, 163.7.

4.9.5 Trans-4-fluorostilbene: ${ }^{31} v_{\max }($ film $) / \mathrm{cm}^{-1} 3025,2921,1513$, 1494, 1448, 1265, 1109, 969, 808, 738, 706, 690; ${ }^{1} \mathrm{H}-\mathrm{NMR}(400$ $\mathrm{MHz}_{\mathrm{CDCl}}$ ) 6.90-7.03 (4 H, m), 7.15-7.32 (4 H, m), 7.37-7.45 (3 H, m); ${ }^{13} \mathrm{C}-\mathrm{NMR}\left(100 \mathrm{MHz}, \mathrm{CDCl}_{3}\right) 115.5,115.7,126.4$, $127.45,127.7,127.9,128.0,128.7,141.3,161.1,163.6$.

Removed the original entry for 4.9.6 as it does not appear in this paper

4.9.6 n-Butyl-trans-cinnamate: ${ }^{29} v_{\max }($ film $) / \mathrm{cm}^{-1} 3061,3028$, 2959, 2933, 2873, 1713, 1638, 1449, 1310, 1280, 1172, 980, 768, 699; ${ }^{1} \mathrm{H}-\mathrm{NMR}\left(400 \mathrm{MHz}, \mathrm{CDCl}_{3}\right) 0.84(3 \mathrm{H}, \mathrm{t}, J=7 \mathrm{~Hz}), 1.27-$ $1.38(2 \mathrm{H}, \mathrm{m}), 1.55-1.62(2 \mathrm{H}, \mathrm{m}), 4.1(2 \mathrm{H}, \mathrm{t}, J=7 \mathrm{~Hz}), 6.31(1$ $\mathrm{H}, \mathrm{d}, J=16 \mathrm{~Hz}), 7.24-7.28(3 \mathrm{H}, \mathrm{m}), 7.37-7.43(2 \mathrm{H}, \mathrm{m}), 7.6(1 \mathrm{H}$, $\mathrm{d}, J=16 \mathrm{~Hz}) ;{ }^{13} \mathrm{C}-\mathrm{NMR}\left(100 \mathrm{MHz}, \mathrm{CDCl}_{3}\right)$ 13.7, 19.1, 30.6, $64.0,117.5,128.4,129.0,130.3,134.5,144.5,166.2$.

4.9.7 Trans-4-chlorostilbene: ${ }^{31} v_{\max }($ film $) / \mathrm{cm}^{-1} 3079,3019,2919$, 1591, 1448, 1405, 1112, 966, 817, 751, 690; ${ }^{1} \mathrm{H}-\mathrm{NMR}(400 \mathrm{MHz}$ $\left.\mathrm{CDCl}_{3}\right) 7.06(2 \mathrm{H}, \mathrm{d}, J=3 \mathrm{~Hz}), 7.25-7.40(5 \mathrm{H}, \mathrm{m}), 7.44(2 \mathrm{H}, \mathrm{d}$, $J=9 \mathrm{~Hz}), 7.51(2 \mathrm{H}, \mathrm{d}, J=7.2 \mathrm{~Hz}) ;{ }^{13} \mathrm{C}-\mathrm{NMR}(100 \mathrm{MHz}$, 
$\left.\mathrm{CDCl}_{3}\right)$ 126.5, 127.4, 127.7, 127.9, 128.7, 128.9, 129.3, 133.2, $135.8,136.9$.

4.9.8 1-Fluoro-3-[(E)-2-(4-methoxyphenyl)vinyl]benzene: ${ }^{32}$ $v_{\max }($ film $) / \mathrm{cm}^{-1} 2932,1600,1508,1489,1232,1098,968,834$; ${ }^{1} \mathrm{H}-\mathrm{NMR}\left(400 \mathrm{MHz} \mathrm{CDCl}_{3}\right) 3.84(3 \mathrm{H}, \mathrm{s}) 6.84-6.96(4 \mathrm{H}, \mathrm{m})$, $7.03(2 \mathrm{H}, \mathrm{t}, J=9 \mathrm{~Hz}), 7.41-7.47(4 \mathrm{H}, \mathrm{m}) ;{ }^{13} \mathrm{C}-\mathrm{NMR}(100 \mathrm{MHz}$, $\left.\mathrm{CDCl}_{3}\right)$ 115.6, 115.8, 127.6, 128.0, 128.1, 128.9, 133.2, 135.6, $161.2,163.7$

4.9.9 1-Chloro-3-I(E)-2-(4-methoxyphenyl)vinyl]benzene: ${ }^{30}$ $v_{\max }($ film $) / \mathrm{cm}^{-1} 2924,2843,1605,1512,1489,1254,1111,1032$, 832, 737, 615; ${ }^{1} \mathrm{H}-\mathrm{NMR}\left(400 \mathrm{MHz} \mathrm{CDCl}_{3}\right) 3.84(3 \mathrm{H}, \mathrm{s}), 6.87-$ $6.94(2 \mathrm{H}, \mathrm{m}), 7.03(2 \mathrm{H}, \mathrm{d}, J=13 \mathrm{~Hz}), 7.31(2 \mathrm{H}, \mathrm{d}, J=12 \mathrm{~Hz})$, 7.43 (4 H, m); ${ }^{13} \mathrm{C}-\mathrm{NMR}\left(100 \mathrm{MHz}, \mathrm{CDCl}_{3}\right) 55.3,114.2,125.6$, $127.4,127.8,128.8,130.2,132.7,136.2,159.5$.

4.9.10 1-Methoxy-3-[(E)-2-(4-methylphenyl)vinyl]benzene: ${ }^{29}$ $v_{\max }($ film $) / \mathrm{cm}^{-1} 3020,2935,2837,1605,1512,1462,1250,1177$, 1110, 1032, 968, 828, 737; ${ }^{1} \mathrm{H}-\mathrm{NMR}\left(400 \mathrm{MHz} \mathrm{CDCl}_{3}\right) 2.28(3$ $\mathrm{H}, \mathrm{s}), 3.75(3 \mathrm{H}, \mathrm{s}), 6.82(2 \mathrm{H}, \mathrm{d}, J=9 \mathrm{~Hz}), 6.87(1 \mathrm{H}, \mathrm{d}, J=16$ $\mathrm{Hz}), 6.95(1 \mathrm{H}, \mathrm{d}, J=16 \mathrm{~Hz}), 7.07(2 \mathrm{H}, \mathrm{d}, J=8 \mathrm{~Hz}), 7.31(2 \mathrm{H}$, $\mathrm{d}, J=8 \mathrm{~Hz}), 7.37(2 \mathrm{H}, \mathrm{d}, J=8 \mathrm{~Hz}) ;{ }^{13} \mathrm{C}-\mathrm{NMR}(100 \mathrm{MHz}$, $\left.\mathrm{CDCl}_{3}\right)$ 21.2, 55.3, 114.1, 126.2, 126.6, 127.2, 127.6, 129.4, $130.4,134.9,137.1,159.2$.

\section{Acknowledgments}

The authors would like to thank Loughborough University for funding a PhD studentship (SPN) and Research Councils UK for a RCUK fellowship (BRB).

\section{References and notes}

1. Beletskaya I. P.; Cheprakov A. V. Chem. Rev., 2000, 100, 3009.

2. Alonso F.; Beletskaya I. P.; Yus M. Tetrahedron, 2005, 61, 50, 11771.

3. (a) Mizoroki, T.; Mori, K.; Ozaki, A. Bull. Chem. Soc. Jpn. 1971, 44, 581; (b) Heck, R. F.; Nolly Jr, J. P. J. Org. Chem. 1972, 37, 2320 .

4. (a) Heck, R. F. Acc. Chem. Res. 1979, 12, 146; (b) De Meijere, A.; Meyer, F. E. Angew. Chem., Int. Ed. Engl. 1995, 33, 2379; (c) Cabri, W.; Candiani, I. Acc. Chem. Res. 1995, 28, 2; (d) Negishi, E.; Coperet, C.; Ma, S.; Liou, S.; Liu, F. Chem. Rev. 1996, 96, 365; (e) Crisp, G. T. Chem. Soc. Rev. 1998, 27, 427; (f) Beletskaya, I. P.; Cheprakov, A. V. Chem. Rev. 2000, 100, 3009; (g) Whitcombe, N. J.; Kuok Hii, K.; Gibson, S. E. Tetrahedron 2001, 57, 7449; (h) Dounay, A. B.; Overman, L. E. Chem Rev. 2003, 103, 2945.

5. For useful reviews covering different aspects of Heck chemistry see for example: (a) Heck, R. F. In Comprehensive Organic Synthesis; Trost, B. M.; Fleming, I. Eds.; Pergamon Press: Oxford, 1991; Vol. 4; (b) Heck, R. F. Org. React. (N.Y.) 1982, 27, 345; (c) Daves, G. D.; Hallberg, A. Chem. Rev. 1989, 89, 1433; (d) De Meijere, A. ; Braese, S. In Transition Metal Catalyzed Reactions; Davies, S. G.; Murahashi, S.-I. Eds.; Blackwell Science: Oxford, 1999; (e) Jeffery, T. In Advances in Metal-Organic Chemistry; Liebeskind, L. S. Ed.; Jai Press Inc: Greenwich, CT, 1996; Vol. 5; (f) Brase, S.; De Meijere, A. In Metal-Catalyzed Cross-Coupling Reactions; Diederich, F.; Stang, P. J. Eds.; Wiley-VCH: New York, 1998; (g) Shibasaki, M.; Boden, C. D. J.; Kojima, A. Tetrahedron 1997, 53, 7371; (g) Overman, L. E. Pure Appl. Chem. 1994, 66, 1423; (h) Link, J. T.; Overman, L. E. In MetalCatalyzed Cross-Coupling Reactions; Diederich, F.; Stang, P. J. Eds.; Wiley-VCH: New York, 1998; (i) Link, J. T. ; Overman, L. E. Chemtech 1998, 28, 19; (j) Gibson, S. E.; Middleton, R. J. Contemp. Org. Synth. 1996, 3,447; (j) Reetz, M. T. In Transition Metal Catalyzed Reactions; Davies, S. G.; Murahashi, S.-I. Eds.; Blackwell Sci.: Oxford, 1999; (k) Dounay, A. B. ; Overman, L. E. Chem. Rev. 2003, 103, 2945.

6. (a) Littke, A. F.; Fu, G. C. J. Org. Chem. 1999, 64, 10; (b) Littke, A. F.; Fu, G. C. J. Am. Chem. Soc. 2001, 123, 6989; (c) Shaughnessy, K. H.; Kim, P.; Hartwig, J. F. J. Am. Chem. Soc. 1999, 121, 2123; (d) Stambuli, J. P.; Stauffer, S. R.; Shaughnessy, K. H.; Hartwig, J. F. J. Am. Chem. Soc. 1999, 121, 2677; (e) Ehrentraut, A.; Zapf, A.; Beller, M. Synlett 2000, 1589.
7. (a) Ben-David, Y.; Portnoy, M.; Gozin, M.; Milstein, D. Organometallics 1992, 11, 1995; (b) Portnoy, M.; Milstein, D. Organometallics 1993, 12, 1655; (c) Portnoy, M.; Ben-David, Y.; Milstein, D. Organometallics 1993, 12, 4734; (d) M. Portnoy, Y. Ben-Dvid, I. Rousso, D. Milstein, Organometallics 1994, 13, 3465; (e) Shaw, B. L.; Perera, S. D. Chem. Commun. 1998, 1863.

8. For recent reviews on palladacycles for Heck reactions, see: (a) Dupont, J.; Pfeffer, M.; Spencer, J. Eur. J. Inorg. Chem. 2001, 1917; (b) Benford, R. B. Chem. Commun. 2003, 1787.

9. For the use of tetraphenylphosphonium salts in Heck reactions, see: Reetz, M. T.; Lohmer, G.; Schwickardi, R. Angew. Chem., Int. Ed. 1998, 37, 481.

10. Phosphine oxidation is a noted problem in bioconjugation. Laughlin, S. T.; Bertozzi, C. R. Nat. Protoc. 2007, 2, 2930.

11. (a) Arduengo, A. J. Acc. Chem. Res. 1999, 32, 913; (b) Herrmann, W. A.; Goossen, L. J.: Köcher, C.; Artus, G. R. J. Angew. Chem., Int. Ed. Engl. 1996, 35, 2805; (c) Herrmann, W. A.; Goossen, L. J.; Artus, G. R. J.; Köcher, C. Organometallics 1997, 16, 2472; (d) Seiders, J.; Ward, D. W.; Grubbs, R. H. Org. Lett. 2001, 3, 3225; (e) Perry, M. C.; Burgess, K. Tetrahedron:Asymmetry 2003, 14, 951; (f) Page, P. C. B.; Buckley, B. R.; Christie, S. D. R.; Edgar, M.; Poulton, A. M.; Elsegood, M. R. J.; McKee, V. J. Organomet. Chem. 2005, 690, 6210.

12. Yang, D.; Chen, Y.-C.; Zhu, N.-Y. Org. Lett. 2004, 6, 1577.

13. (a) Nan, Y.; Miao, H.; Yang, Z. Org. Lett. 2000, 2, 297; (b) Miao, H.; Yang, Z. Org. Lett. 2000, 2, 1765; (c) Hu, Y.; Yang, Z. Org. Lett. 2001, 3, 1387.

14. (a) Buchmeiser, M. R.; Schareina, T.; Kempe, R.; Wurst, K. J. Organomet. Chem. 2001, 634, 39; (b) Masllorens, J.; MorenoMañas, M.; Pla-Quintana, A.; Roglans, A. Org. Lett. 2003, 5, 1559; (c) Masllorens, J.; Roglans, A. Organomet. 2004, 23, 2533; (d) Chalker, J. M.; Wood, C. S. C.; Davies, B. G. J. Am. Chem. Soc. 2009, 131, 16346

15. (a) Hultén, J.; Bonham, N. M.; Nillroth, U.; Hansson, T.; Zuccarello, G.; Bouzide, A.; Åqvist, J.; Classon, B.; Danielson, U. H.; Karlén, A.; Kvarnström, I.; Samuelsson, B.; Hallberg, A. J. Med. Chem. 1997, 40, 885; (b) Bäckbro, K.; Löwgren, S.; Österlund, K.; Atepo, J.; Unge, T.; Hultén, J.; Bonham, N. M.; Schaal, W.; Karlén, A.; Hallberg, A. J. Med. Chem. 1997, 40, 898.

16. Castro, J. L.; Matassa, V. G.; Ball, R. G. J. Org. Chem. 1994, 59, 2289.

17. (a) Ahn, K.-H.; Yoo, D.-J.; Kim, J.-S. Tetrahedron Lett. 1992, 33, 6661; (b) Pansare, S. V.; Rai, A. N.; Kate, S. N. Synlett 1998, 623; (c) Sartor, D.; Saffrich, J.; Helmchen, G.; Richards, C. J.; Lambert, H. Tetrahedron: Asymmetry 1991, 2, 639; (d) Oppolzer, W.; Starkemann, C.; Rodriguez, I.; Bernadinelli, G. Tetrahedron Lett. 1991, 32, 61; (e) Oppolzer, W.; Kingma, A. J.; Pillai, S. K. Tetrahedron Lett. 1991, 32, 4893.H.G. Richey, Jr., J. Farkas, Jr., J. Org. Chem. 1987, 52, 479.

18. Richey Jr. H. G.; Farkas Jr. J. J. Org. Chem. 1987, 52, 479.

19. (a) Dewynter, G.; Ubaldi, S.; Voyer, N.; Toupet, L. Tetrahedron Lett. 1998, 39, 7434; (b) Boudjabi, S.; Dewynter, G.; Voyer, N.; Toupet, L. Eur. J. Org. Chem. 1999, 9, 2275; (c) Regainia, Z.; Abdaoui, M.; Aouf, N. E.; Dewynter, G.; Montero, J. L. Tetrahedron 2000, 56, 381.

20. Buckley, B. R.; Neary, S. P. Adv. Synth. Catal. 2009, 351, 71.

21. Using a Biotage Initiator Eight EXP Microwave System.

22. Initially when the $\mathrm{Pd}_{2}(\mathrm{dba})_{3}$-ligand solutions were prepared they took on a dark red colour. After sufficient stirring they gradually changed to a bright yellow, indicating generation of the active form. When making larger stock solutions we observed that the activation times could be significantly longer with significant amounts of palladium black precipitating in the process. We later found that the activation times were improved by exposing as much of the surface area of the solution as possible to air while stirring vigorously. The palladium black can simply be filtered from the solution or allowed to settle to the bottom of the container, while the solution is taken from the surface. We later discovered that by doubling the number of equivalents of ligand, the palladium black precipitate was eliminated from the stock solution.

23. Katritzky, A. R.; Fan, J.; Fu, C. J. Org. Chem. 1990, 55, 10, 3209.

24. (a) Amatore, C.; Jutland, A. Acc. Chem. Res. 2000, 33, 314; (b) Amatore, C.; Carré, E.; Jutland, A.; Medjour, Y. Organometallics 2002, 21, 4540.

25. Amatore, C.; Carré, E.; Jutland, A.; Shaik, S. Organometallics 2002, 21, 2319.

26. Henriksen, S. T.; Norrby, P. O.; Kaukoranta, P.; Andersson, P. G. J. Am. Chem. Soc. 2008, 130, 10414 and references cited therein. 
27. Reetz, M. T. ; Westermann, E.; Lohmer, R.; Lohmer, G.

Tetrahedron Lett. 1998, 8449

28. Willans, C. E.; Mulders, J. M. C. A.; de Vries, J. G.; de Vries, A.

H. M. J. Organomet. Chem. 2003, 687, 494.

29. Kantam, M. L.; Srinivas, P.; Yadav, J.; Likhar, P. R.; Bhargava, S.; J. Org. Chem. 2009, 74, 4882.

30. Prukała, W.; Majchrzak, M.; Pietraszuk, C.; Marciniec, B. J. Mol. Cat. A: Chem. 2006, 254, 58.

31. Luo, F.; Pan, C.; Wang, W.; Ye, Z.; Cheng, J. Tetrahedron 2010, $66,1399$.

32. Shi, M.; Xu, B. J. Org. Chem. 2002, 67, 294.

33. Zhou, P.; Li, Y.; Sun, P.; Zhou, J.; Bao, J. Chem. Commun., 2007, 1418.

34. Douglas, R. A.; Crabtree, R. H. Organometallics 1983, 2, 855.

35. (a) Fairlamb, I. J. S. Org. Biomol. Chem., 2008, 6, 3645; (b) Fairlamb, I. J. S.; Kapdi, A. R; Lee, A. F.; McGlacken, G. P.; Weissburger, F.; de Vries A. H. M.; Schmieder-van de Vondervoort, L. Chem. Eur. J., 2006, 12, 8750. 